\title{
The factors of financial report transparency in the regional government
}

Sumartono

Faculty of Economics, Universitas Yapis Papua, Jayapura, Indonesia sumartono@uniyap.ac.id

Muhammad Ridhwansyah Pasolo

Faculty of Economics, Universitas Yapis Papua, Jayapura, Indonesia

Follow this and additional works at: https://journal.uii.ac.id/jca

Copyright (C2019 Journal of Contemporary Accounting and Authors.

To cite this article: Sumartono \& Muhammad Ridhwansyah Pasolo. (2019). The factors of financial report transparency in the regional government. Journal of Contemporary Accounting, 1(1), 11-25. doi:10.20885/ica.vol1.iss1.art2 


\title{
The factors of financial report transparency in the regional government
}

\author{
Sumartono ${ }^{1}$, Muhammad Ridhwansyah Pasolo ${ }^{2}$ \\ ${ }^{1,2}$ Faculty of Economics, Universitas Yapis Papua, Jayapura, Indonesia
}

\begin{abstract}
JEL Classification:
M48, G38

Keywords:

Transparency, financial report, regional government, policy
\end{abstract}

\section{Corresponding Author:}

sumartono@uniyap.ac.id

DOI:

10.20885/jca.vol1.iss 1.art2

Copyright (C) 2019

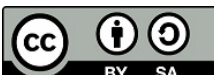

This is an open access under CC-BY-SA license

\begin{abstract}
This research is aimed at investigating the empirical factors affecting the financial report transparency in the regional government of Papua province. The quantitative approach was used in this research. 92 comprehensive questionnaires were analyzed quantitatively. The double linear regression analysis shows that the financial report presentation, accessibility, and internal control significantly affect the financial report transparency in the regional government. This research implies important contribution that the empirical findings of the effect of financial report presentation, accessibility, and internal control system on the financial report transparency in the regional government are expected to foster constructive recommendations in the form of policy related to the financial report transparency in the regional government.
\end{abstract}

\section{Introduction}

The concern on the transparency and accountability issues of public finance is possibly relevant to discuss by the rationale of fiscal decentralization factors given by the central to the regional government. There have been significant changes in the composition of the cost, both in the central and regional government, as the regional autonomy consequences (Aliyah \& Nahar, 2012). Transparency itself is a mechanism used to increase the good governance system of public services and to develop public capabilities to access government information (Bauhr \& Grimes, 2013; Piotrowski \& Ryzin, 2007).

The changes in the public sector introduced in the last decades are generally reflected by the culture of administration, organization openness, and the improvement of accountability and transparency mechanism (Araujo \& Tejedo-Romero, 2016). Therefore, reforming the accounting and financial management systems is a necessary need that is later commonly conducted in order to meet the public transparency and accountability of the regional government in managing public finance (Sukhemi, 2010).

One of the requirements to make it happen is by reforming the financial report, in which the government should be able to provide sufficient and transparent financial information to the public (Aliyah \& Nahar, 2012).

However, empirically, the regional government cannot fully reform its accounting and financial management system to meet the transparency characteristics. It is proven by the access of public information, both in the form of printed and electronic media, which is not opened yet. Moreover, there is still low access for the regional government finance in some places, especially under the Papua province.

Based on the monitoring, evaluation, and advocacy conducted by the Papua Commission of Information during 2015 reported to the Regional Working Unit (SKPD) of Papua province, it 
is revealed that: (1) there is still lack of obedience performed by SKPD in announcing the information of Performance Accountability Report (LAKIP) 2014 including the financial report; and (2) almost all public boards announce the cost plan of 2013 and its realization through the website (only $2(4 \%)$ SKPD announce it and $2(4 \%)$ announce the realization). Viewing this phenomenon, it is clearly indicated that the level of transparency and accountability of financial report in Papua province is still low.

In addition, some problems are also depicted in previous research. It is revealed that financial report transparency in the regional government is affected by some factors as follows: the presentation and accessibility of regional financial report, management commitment, level of prosperity, organizational factors such as financial condition, government welfare, and political competition, and environment factors such as the size of organization and the level of income (Aliyah \& Nahar, 2012; Bolívar, Muñoz, \& Hernández, 2013; Dewi, Sujana, \& Sinarwati, 2015; Masyhur, Hardi, \& Silfi, 2017; Mustofa, 2012; Rahmawati \& Mahmudi, 2016; Sari, 2012).

Compared to some previous research, this research applies different characteristics of the research object. The object of this research is the regional government in Papua province which is one of the regions with special autonomy. Geographically, the location of Papua province covers a wide area and a long distance measured from the central government access. In short, this research is needed to conduct because the financial report transparency in the regional government of Papua province is still low. Therefore, the researcher intends to identify some potential factors affecting the financial report transparency in the regional government of Papua province.

\section{Literature Review and Hypothesis Development}

\section{Financial Report Presentation}

According to Aditya and Surjono (2017) financial report is a structured reporting about the financial condition and transactions done by a reporting entity. Generally, the aim of a financial report is to provide the information of financial condition, cost realization, cash-flow cycle, and financial performance of a reporting entity that is beneficial to its users in creating and evaluating the decision of the allocation of the resources. Specifically, the government financial report is to provide information beneficial to make a decision and to show the accountability of a reporting entity for the resources given to them, by:

1. Providing information about financial resources condition, responsibility, and government welfare equity.

2. Providing information on the changes in financial resources, responsibility, and government welfare equity.

3. Providing information about sources, allocations, and the use of financial resources.

4. Providing information on the obedience of realization towards the cost.

5. Providing information about the way the reporting entity financing the activities and fulfilling the need of its cash.

6. Providing information about the government's potential to finance government activities.

7. Providing information that is beneficial to evaluate the capability of reporting entity in recording their activities.

The components of the financial report are a set of report which consists of: (1) Cost Realization Report; (2) Credit Changes of Surplus Cost Report; (3) Balance; (4) Operational Report; (5) Cash-Flow Cycle Report; (6) Equity Changes Report; (7) Financial report Note. The financial report provides information on financial resources and the responsibilities of the reporting entity on the date of reporting and the cycle of financial resources during the period. This information is needed by the users to assess the capability of reporting entity in conducting the future governance 
activities. The components of the financial report are provided by every entity, which is meant by every unit of organization.

The reporting entity provides information to help the users in predicting the result of its operation asset management, such as in creating and evaluating the decision on the allocation of financial resources. In short, the financial report presentation is a very important factor.

As stated in the Statement of Governance's Standard Accounting (PSAP) No. 1, paragraph 49 (Peraturan Pemerintah, 2010), balance provides at least the following posts: cash or the equivalent, short-term investment, tax and non-tax payers, presentation: long-term investment, permanent assets, short- and long-term responsibilities, and finance equity.

The aim of the public sector's financial report according to the Governmental Accounting Standard Board (1998) is to help the government's responsibility to be publicly accountable and to help the users fulfill their needs in terms of limited access, limited capability or resources to gain information that they depend on the report as an important source. For this reason, the financial report should consider the users' needs and their decision.

\section{Financial Report Accessibility}

Safitri (2009) states that accessibility in the perspective of space management is the condition or presentation of relationship from one place to another, or the ease of a person or a vehicle to move from one place to another safely, comfortably, and fast. On the other hand, Mulyana (2006) opines that accessibility in a financial report is the ease of a person to get financial report information.

The rights of the public on financial information appears as the consequence of public accountability. It requires the public organization to provide a financial report as proof for their accountability and stewardship. Societies as the party who give trust to the government to manage public finance possess the rights to get information about the government's finance in order to evaluate them (Mardiasmo, 2018). Therefore, the government is compulsorily giving financial information that is going to be used to make economic, social, and political decisions by related parties. The information of regional government financial report is able to meet the transparency and accountability principles when they keep improving the accessibility of their financial report. It can be achieved by facilitating some related parties to be able to know or to get the financial report easily.

In an open democracy, the access of financial report is provided in some media such as newspaper, magazine, TV, and the Internet. The accessibility of financial report acts as the ease of a person to get financial report information (Mulyana, 2006). In addition, Shende and Bennett (2004) state that besides the mentioned media, the access is also provided by some forums which have direct concern or role supporting the accountability of the government to the societies.

\section{Internal Control System}

According to Yendrawati (2013) internal control system is a process conducted by the commission and management boards, and other parties designed to give relevant trust about the achievement of the following three aspects: a) the credibility of the financial report; b) the effectiveness and the efficiency of the operation; and c) the obedience towards the law and regulation. The government internal control system becomes the instrument that functions as the tool of the government cost control so that there will be no excess in the outcome.

\section{Report Transparency in the Regional Government}

Transparency means the openness of the government to give information related to the activities of the management of public resources to the parties who need it. The government is compulsory to give financial information as well as the other information which will be used to make decision conducted by the related parties. The public transparency requires each public official to 
compulsorily open a participation space to the societies in creating public policies by opening the access and giving trustworthy, honest, and non-discriminative information, whether requested by the societies or not (Yogaperwira, 2008). The transparency in the regional government requires the openness of the regional government themselves in the process of decision, policy, or report making - the reporting of their work, so the public is able to know, analyze, and give feedback as well as supervise the governance. In the end, transparency can create horizontal accountability between the government and the societies, so good governance appears at the regional level. Loina (2003) define transparency as the principles that give a guarantee of access or freedom to individuals to get information about the governance, such as the process of policy making and its conduct, the achievements gained, and other results that can be applied in some public activities (Sol, 2013).

Sari (2012) explains that transparency is when individuals, groups, or organizations in the relation of accountability are led without any lies or implied motivation and that all performance information is complete and has no aims to eliminate data related to certain problems. Moreover, Nordiawan (2012) states that transparency is giving open and honest financial information to the societies based on the consideration that the societies have rights to know the government accountability openly and comprehensively in managing the resources trusted to them and how obedient they are to the regulated Acts.

\section{Financial Report Presentation and Transparency in the Regional Government}

Financial report provides information about financial resources and the responsibility of the reporting entity on the date of the reporting and the financial resources cycle during the related period. This information is needed by the users to assess the capability of the reporting entity in conducting future governance activities. The components of the financial report are provided by every entity, which is meant by every unit of organization.

The reporting entity provides information to help the users in predicting the result of its operation asset management, such as in creating and evaluating the decision on the allocation of financial resources. In short, the financial report presentation is a very important factor.

As stated in the Statement of Governance's Standard Accounting (PSAP) No. 1, paragraph 49 (Peraturan Pemerintah, 2010), balance provides at least the following posts: cash or the equivalent, short-term investment, tax and non-tax payers, presentation: long-term investment, permanent assets, short- and long-term responsibilities, and finance equity.

Viewing the PSAP mentioned above, the posts in the financial report possess the presentation standard, so the complete financial report presentation is expected to potentially improve the financial report transparency in the regional government. By doing so, the transparency will create accountability in the future (Nordiawan, 2012).

The previous research reveals that the presentation of financial report affects the financial report transparency in the regional government (Aliyah \& Nahar, 2012; Masyhur et al., 2017). This argument becomes the base of the hypothesis proposed in this research as follow:

H1: The financial report presentation affects the financial report transparency in the regional government.

\section{Financial Report Accessibility and Transparency in the Regional Government}

Accessibility is a process of revealing financial report to be able to consume by the public. Good accessibility will create a good relationship between the public and the government (Mustofa, 2012). Moreover, Mulyana (2006) states that accessibility in the financial report is seen as the ease of a person to get the financial report information.

In an open democracy, the access of financial report is provided in some media such as newspaper, magazine, TV, and the Internet. This access is also provided by some forums which 
have direct concern or role supporting the accountability of the government to the societies (Shende \& Bennett, 2004).

In order to meet the principles of transparency and accountability, the information stated in the regional government's financial report should not only be reported to the Regional Parliamentary Board $(D P R D)$, but also to the societies. It means that the regional government should increase their financial report accessibility by facilitating the societies to know and to get the financial report easily (Aliyah \& Nahar, 2012). Masyhur et al. (2017) states that the accessibility of the regional government's financial report affects the transparency of its management, so the hypothesis proposed in this research is constructed as follow:

H2: The accessibility affects the financial report transparency in the regional government.

\section{Internal Control and Financial Report Transparency in the Regional Government}

Internal control is defined as a process affected by the commission board, direction/top management, and other parties which is constructed to gain trustworthiness on the achievements such as: a) the financial report credibility, b) the obedience towards the Acts and the regulated rules, and c) the effectiveness and efficiency of the operation (Agoes, 2017).

The necessity of conducting the internal control system in each reporting entity and accounting is emphasized by the Peraturan Pemerintah (PP) Number 60, 2008 which explicitly regulates the Government Internal Control System (SPIP). Conceptually, it refers to the definition of internal control proposed by the Committee of Sponsoring Organizations (COSO) (Sari, 2012).

In the context of governance, through the PP Number 60, 2008, the government regulates an internal control system which is compulsorily conducted, both in the level of the central and regional government. The internal control system meant here is a process integrated to the acts and activities done continually by the chairpersons and all staffs to provide trustworthiness on the achievement of the organization's aims through the effective and efficient activities, credible financial report, maintenance and safety of the government's assets, and the obedience towards the Acts. In other words, the internal control system is beneficial, especially to control the governance activities, to improve the transparency of the state' financial management. The research conducted by Masyhur et al. (2017) and Sari (2012) reveals that internal control affects the financial report transparency in the regional government. The hypothesis in this research is proposed as follow:

H3: The internal control system affects the financial report transparency in the regional government.

\section{Research Method}

\section{Population and Sample}

The population of this research was the Civil Servants $(A S N)$ working at SKPD of Papua province. The purposive sampling technique was applied and got the samples from the staffs who had been working for at least 2 years from the Financial Board, the Treasurers of Credit and Debit, the Government Management Information System (SIMDA), and the Cost User Control $(K P A)$ who was responsible to the management of financial report in each SKPD. The sample taken from each $S K P D$ was 3 (listed in the appendix). The data used in this research were the primary data gained through the questionnaires using 5 Likert's scales. The respondents' answers were scored as follows: Score $1=$ strongly disagree, Score $2=$ disagree, Score $3=$ neutral $/$ doubt, Score $4=$ agree, and Score $5=$ strongly agree. 


\section{Operational Definition of the Research Variable}

\section{Dependent variable}

The dependent variable of this research is the financial report transparency in the regional government. The indicators used to measure this variable are adopted from Nurrizkiana, Handayani, and Widiastuty (2017): the presentation of the information system, the accessibility of the regional financial report, the publication of the regional financial report, the presentation of checking report, and the presentation of performance report.

\section{Independent variable}

The presentation of the financial report in this research is a structured presentation report about financial condition and transactions done by the reporting entity that fulfills the characteristics of qualified government financial report and suit to the Government Accounting Standard. The indicators used to measure this variable are adopted from Nurrizkiana et al. (2017) based on the Government Regulation No. 71, 2010 about the Governance Accounting Conceptual Framework stating that the qualitative characteristics of required government financial report are: 1) relevant, 2) credible, 3) comparable, and 4) understandable.

The accessibility of the financial report in this research is the ability to give access to stakeholders to know or to get the financial report as part of their participation. The indicators used to measure this variable is adopted from Nurrizkiana et al. (2017) based on the Act No. 33, 2004 Article 103 which states that the information depicted in the regional financial information system is opened data which can be known, accessed, and gained by the societies.

The internal control system is a process affected by all organizational structures and the related procedures which are managed to gain relevant trustworthiness on the achieved aims (Sari, 2012). The 5 indicators used to measure this variable are adopted from Aditya and Surjono (2017): the control environment, the risk assessment, the control activities, the information and communication, and the supervision. Four indicators are used in this research.

\section{Results and Discussion}

\section{The Test of Research Instrument}

This research uses primary data. The instrument used to gain the research data is a questionnaire. Before distributing the questionnaires to the respondents, the items that should be answered by the respondents are tested to gain validity and reliability.

\section{Validity Test}

The validity test is conducted to know whether all items in the questionnaires to measure the variables are valid. The validity test is conducted using statistics program with the following criteria: if $r$ test is positive ( $r$ test $>\mathrm{r}$ table), the items are valid; if $\mathrm{r}$ test is negative $(\mathrm{r}$ test $<\mathrm{r}$ table), the items are not valid. The $\mathrm{r}$ table value is gained through the $\mathrm{df}$ (degree of freedom) $=n-2$, where $n$ $=$ the number of the research sample. The result of the validity test in this research uses the significance $5 \%, \mathrm{df}=92-2=90$ (Ghozali, 2016), with the $\mathrm{r}$ table 0.207 . The result of the validity test of each variable can be viewed in Table 1.

Table 1 shows that all statement items in the questionnaires are valid because $\mathrm{r}_{\text {test }}$ is positive and $r_{\text {test }}>r_{\text {table. }}$ Therefore, the next step, which is the reliability test, can be conducted. 
JCA | Volume 1, No.1, 2019

Table 1. The Result of the Validity Test

\begin{tabular}{|c|c|c|c|c|}
\hline Variable & $\begin{array}{c}\text { Statement } \\
\text { Items }\end{array}$ & $\mathrm{r}_{\text {test }}$ & $\mathrm{r}_{\text {table }}$ & Result \\
\hline Financial Report Presentation & 1 & 0.551 & 0.207 & Valid \\
\hline \multirow[t]{6}{*}{$(\mathrm{X} 1)$} & 2 & 0.702 & 0.207 & Valid \\
\hline & 3 & 0.554 & 0.207 & Valid \\
\hline & 4 & 0.532 & 0.207 & Valid \\
\hline & 5 & 0.499 & 0.207 & Valid \\
\hline & 6 & 0.751 & 0.207 & Valid \\
\hline & 7 & 0.647 & 0.207 & Valid \\
\hline \multirow[t]{3}{*}{ Accessibility (X2) } & 1 & 0.805 & 0.207 & Valid \\
\hline & 2 & 0.807 & 0.207 & Valid \\
\hline & 3 & 0.773 & 0.207 & Valid \\
\hline \multirow[t]{4}{*}{ Internal Control System (X3) } & 1 & 0.724 & 0.207 & Valid \\
\hline & 2 & 0.724 & 0.207 & Valid \\
\hline & 3 & 0.770 & 0.207 & Valid \\
\hline & 4 & 0.712 & 0.207 & Valid \\
\hline Financial Report Transparency in the Regional & 1 & 0.812 & 0.207 & Valid \\
\hline Government & 2 & 0.736 & 0.207 & Valid \\
\hline \multirow[t]{3}{*}{ (Y) } & 3 & 0.656 & 0.207 & Valid \\
\hline & 4 & 0.734 & 0.207 & Valid \\
\hline & 5 & 0.700 & 0.207 & Valid \\
\hline
\end{tabular}

Source: data were managed in 2018.

\section{Reliability Test}

The reliability test in this research is measured with Cronbach Alpha Coeficient. If the value of Cronbach Alpha > 0.7 (Nunnally, 1967), the construct is considered as reliable. The result of the reliability test of each variable of this research can be viewed in Table 2 .

Table 2. The Result of the Reliability Test

\begin{tabular}{clcl}
\hline No & \multicolumn{1}{c}{ Variable } & Cronbach's Alpha & Result \\
\hline 1. & Financial Report Presentation (X1) & 0.703 & Reliable \\
2. & Accessibility (X2) & 0.704 & Reliable \\
3. & Internal Control System (X3) & 0.708 & Reliable \\
4. & Financial Report Transparency in the & 0.776 & Reliable \\
\hline
\end{tabular}

Source: data were managed in 2018

Table 2 shows that all statement items in each research variable are reliable because of the value of Cronbach's Alpha $>0.7$. The quality test of the data is conducted using the classic assumption test by viewing the aspect of Normality, Multicollinearity, and Heteroscedasticity.

The Normality test in this research is conducted with Kolmogorov-Smirnov test: if the significance value or probability $<0.05$, the data distribution is not normal; if the significance value or probability $>0.05$, the data distribution is normal. In this research, it is gained that the sig. value (2-tailed) is 0.087 . It means that the sig. value ( 2 -tailed) $0.087>0.05$. It can be concluded that the data distribution of this research is normal (Ghozali, 2016).

The Multicollinearity test in this research shows that the VIF value of each variable Financial Report Presentation (3.068), Accessibility (2.140), and Internal Control System (2.120) is no more than 10. Meanwhile, the value of variable tolerance - Financial Report Presentation 
(0.326), Accessibility (0.467), and Internal Control System (0.472) - is no less than 0.1. It can be concluded that there is no Multicollinearity (Ghozali, 2016).

Heteroscedasticity is detected by viewing whether a certain pattern on the scatterplot around the value of $\mathrm{X}_{1}, \mathrm{X}_{2}, \mathrm{X}_{3}$, dan $\mathrm{Y}$ exists or not. If there is a certain pattern, the Heteroscedasticity exists (Ghozali, 2016). The Heteroscedasticity test is conducted using SPSS Ver. 25 software which is shown in Figure 1. Based on the result of scatterplot analysis, it is viewed that the dots are spread randomly without shaping a certain pattern. The dots are spread both above and under 0 on the $\mathrm{Y}$-axis. This result shows that there is no Heteroscedasticity on the model of regression. It can be concluded that there is no Heteroscedasticity in all variables, or, in another word, it contains Homoscedasticity.

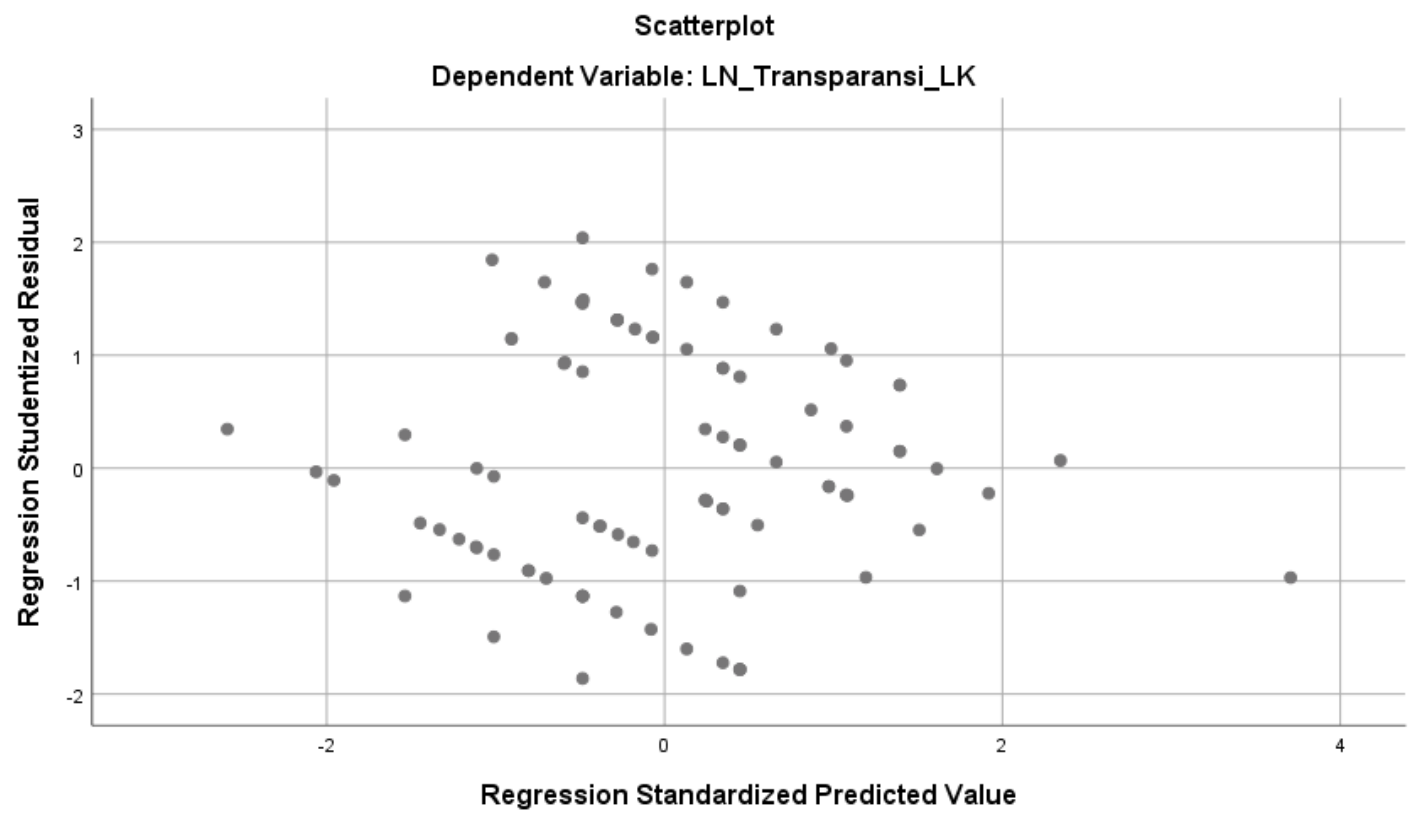

Figure 1. Scatterplot (Heteroscedasticity Test)

\section{Hypothesis Test}

The t-test is conducted to analyze the effect of independent variables on the dependent variable. The test is conducted by comparing the value of $\mathrm{t}$-test with the value of $\mathrm{t}$ table, or by viewing the level of significance (P-value) that if $\mathrm{p}$-value $<0.05$, there is a significant effect ( $\mathrm{Ha}$ is supported and $\mathrm{Ho}$ is not supported). Meanwhile, if $\mathrm{P}$-value $>0.05$, there is no significant effect ( $\mathrm{Ha}$ is not supported and Ho is supported). The results of the test are shown in Table 3.

Table 3. The Result of Double Linear Regression Test

\begin{tabular}{lcccc}
\hline \multicolumn{1}{c}{ Variable } & $\begin{array}{c}\text { Regression } \\
\text { Coefficient }(\beta)\end{array}$ & $\mathrm{t}_{\text {test }}$ & P Value & \multirow{2}{*}{ Result } \\
\hline Financial Report Presentation $\left(\mathrm{X}_{1}\right)$ & -.026 & -4.530 & .000 & Significant \\
Accessibility $\left(\mathrm{X}_{2}\right)$ & .036 & 4.270 & .000 & Significant \\
Internal Control System $\left(\mathrm{X}_{3}\right)$ & .031 & 4.442 & .000 & Significant \\
Constanta $(\alpha)$ & 2.872 & 27.977 & .000 & \\
Adjusted R Square & & & & .305 \\
$\mathrm{~N}$ & & & & 92 \\
\hline
\end{tabular}

Dependent Variable: Financial Report Transparency

Source: data were managed in 2018 
Table 3 shows that there are 3 variables which significantly affect the Financial Report Transparency. The Financial Report Presentation negatively affects the Financial Report Transparency, while the Accessibility and the Internal Control System positively affect the Financial Report Transparency.

Based on the result of the analysis in Table 3 , it is revealed that the determination coefficient (adjusted $\mathrm{R}^{2}$ ) is 0.305 . It means that the Financial Report Presentation $\left(\mathrm{X}_{1)}\right.$, Accessibility $\left(\mathrm{X}_{2}\right)$, and Internal Control System $\left(\mathrm{X}_{3}\right)$ have a significant effect as much as $30.5 \%$ on the Financial Report Transparency in the Regional Government (Y). The other $69.5 \%$ is affected by other factors out of this research.

The discussion of the results of the double linear regression analysis for each independent variable is provided as follow.

\section{The Effect of Financial Report Presentation on the Financial Report Transparency in the Regional Government}

The result of t-test as shown in Table 3 describes that the Financial Report Presentation $\left(\mathrm{X}_{1}\right)$ has $\mathrm{t}_{\text {test }}-4.530$ and $\mathrm{t}_{\text {table }} 1.987$ with $(\mathrm{n}-\mathrm{k}=92-4=88)$, while the P-value 0.000 is under the value of $\alpha$ $=0.05$. In other words, the value of $\mathrm{t}_{\text {test }}-4.530>\mathrm{t}_{\text {table }}$ 1.987. It means that $\mathrm{Ha}$ is supported and Ho is not supported. This result shows a negative effect, which is different from the research conducted by Aliyah and Nahar (2012) and Masyhur et al. (2017) which results in a positive effect.

Based on the empirical result in this research, it can be explained that even though the financial report is provided completely, on time, and understandable that it is influential and beneficial to the decision making, it is not impossible that the transactions conducted do not suit the regulated Acts and are not provided in a trustful way, especially the material issues. In other words, it lacks transparency. One of the factors causing this problem is that the regional government financial management cannot be separated from the political issue Bolívar et al. (2013) which involves both executive and legislative parties. There might be some implied purposes form those two parties that later affect the sufficient information related to the whole regional cost spent by the regional government in a certain period of time.

\section{The Effect of Accessibility on the Financial Report Transparency in the Regional Government}

The result of t-test in Table 3 describes that the Accessibility $\left(\mathrm{X}_{2}\right)$ has $\mathrm{t}_{\text {test }} 4.270$ and table 1.987 with $(\mathrm{n}-\mathrm{k}=92-4=88)$, while P-value 0.000 is under the value of $\alpha=0.05$. In other words, $\mathrm{t}_{\text {test }} 4.270$ $>t_{\text {table }}$ 1.987. It means that $\mathrm{Ha}$ is supported and Ho is not supported. It can be concluded that the Accessibility partially affects the Financial Report Transparency in the Regional Government.

Based on the empirical result, it is revealed that the easier the accessibility, the more potential it is to improve the financial report transparency in the regional government. By giving the ease of access to the users, transparency is created. It means that the regional financial management is better and the public's trust in the regional government is gained successfully. It is supported by the capability of each $S K P D$ to ease the access service given to all regional financial report users that they have sufficient information technology infrastructure. On the other hand, the infrastructure is not maximally utilized yet. Moreover, some regions are not facilitated by this infrastructure. Therefore, this description should be used as a reflection to improve the accessibility of the regional financial report as the consequence of the regulated Acts implementation. The result of this research is in line with Aliyah and Nahar (2012) and Masyhur et al. (2017) who say that the Accessibility affects positively and significantly on the Financial Report Transparency in the Regional Government. 


\section{The Effect of Internal Control System on the Financial Report Transparency in the Regional Government}

The result of t-test in Table 3 describes that the Internal Control System $\left(\mathrm{X}_{3}\right)$ has $\mathrm{t}_{\text {test }} 4.442$ and $\mathrm{t}_{\text {table }}$ 1.987 with ( $\mathrm{n}-\mathrm{k}=92-4=88$ ), while the P-value 0.000 is under the value of $\alpha=0.05$. In other words, the value of $\mathrm{t}_{\text {test }} 4.442>\mathrm{t}_{\text {table }}$ 1.987. It means that $\mathrm{Ha}$ is supported and $\mathrm{Ho}$ is not supported. It can be concluded that the Internal Control System partially affects the Financial Report Transparency in the Regional Government.

A sufficient internal control covers a clear job description, sufficient portion and procedure of recording, and good practice. Through a good internal control, it is expected that the orders from the chairpersons are conducted well with a minimum mistake, fraud, abuse, or disobedience towards the regulated Acts related to the regional financial management. Each unit of SKPD is able to manage finance better and structurally. In the end, the transparency and accountability of the regional financial management are achieved and there is a public's trust to the regional government. It is supported by the capability of chairperson in each unit of SKPD to continually supervise and give clear knowledge about the management system to the staffs as well as to implement it consistently.

The result of this research is in line with Aliyah and Nahar (2012) and Masyhur et al. (2017) who reveal that the Internal Control System affects significantly on the Financial Report Transparency in the Regional Government.

Based on the analysis result in Table 3, the biggest value of $t_{\text {test }}$ is in the variable of the Internal Control System with 4.405. It means that the Internal Control System has the most significant effect compared to the other two variables - the Financial Report Presentation and the Accessibility - on the Financial Report Transparency in the Regional Government.

\section{Conclusion}

The value of adjusted $R^{2}$ or the capability to explain all variables being researched on the transparency here is quite low, which is $30.5 \%$. Therefore, this research is not yet contributing sufficiently to the factors affecting the financial report transparency in the regional government. Based on the empirical results in this research, the regional Financial Report Presentation does not always have potential matters to improve the Financial Report Transparency. It is not impossible that the transactions conducted do not suit the regulated Acts and are not provided in a trustful way, especially the material issues. In other words, it lacks transparency. One of the factors causing this problem is that the regional government financial management cannot be separated from the political issue which involves both executive and legislative parties. There might be some implied purposes form those two parties that later affect the sufficient information related to the whole regional cost spent by the regional government in a certain period of time.

The variable of Accessibility shows a positive effect on the Financial Report Transparency. It means that the more the regional government gives access to the information related to the regional government financial report, the more the public trust the government itself. Therefore, through the provided information access, the public's trust in the government increases in line with the Financial Report Transparency betterment.

The variable of the Internal Control System shows a positive effect on the Financial Report Transparency. It means that good internal control is expected to support the chairperson's orders can be conducted well with a minimum mistake, fraud, abuse, or disobedience towards the regulated Acts related to the regional financial management. Each unit of SKPD is able to manage finance better and structurally. In the end, the transparency and accountability of the regional financial management are achieved and there is a public's trust to the regional government.

This research implies important contribution that the empirical findings of the effect of financial report presentation, accessibility, and internal control system on the financial report 
transparency in the regional government are expected to foster constructive recommendations in the form of policy related to the financial report transparency in the regional government.

The future research is expected to apply the primary data collection method using questionnaires or interviews by adding some other variables such as financial condition, welfare among government, political competition, organization size, and the level of income.

\section{Acknowledgement}

The authors would like to acknowledge the support provided by the Directorate General of Strengthening for Research and Development of Indonesia (Ristekdikti) through the 2018 Beginner Lecturer Grant (Hibah Dosen Pemula) for the funding of this study.

\section{References}

Aditya, O. R., \& Surjono, W. (2017). Pengaruh sistem pengendalian intern terhadap kualitas laporan keuangan. Jurnal Sistem Informasi, Keuangan, Auditing Dan Perpajakan, 2(1), 49-62.

Agoes, S. (2017). Auditing:Petunjuk Praktis Pemeriksaan Akuntan oleh Akuntan Publik (edisi 5). Jakarta: Salemba Empat.

Aliyah, S., \& Nahar, A. (2012). Pengaruh penyajian laporan keuangan daerah dan aksesibilitaslaporan keuangan daerah terhadap transparansi dan akuntabilitas pengelolaan keuangan daerah kabupaten Jepara. Jurnal Akuntansi \& Auditing, 8(2), 137-150.

Bauhr, M., \& Grimes, M. (2013). No Title. Governance, 27(12), 291-320. https://doi.org/10.1111/gove.12033

Bolívar, M. P. R., Muñoz, L. A., \& Hernández, A. M. L. (2013). Determinants of financial transparency in government. International Public Management Journal, 16(4), 557-602. https://doi.org/10.1080/10967494.2013.849169

Dewi, N. W. S., Sujana, E., \& Sinarwati, N. K. (2015). Pengaruh tekanan eksternal, faktor politik, dan komitment manajemen terhadap penerapan transparansi pelaporan keuangan (Studi kasus pada SKPD kabupaten Karangasem). Jurnal Ilmiah Mahasiswa Akuntansi Undiksha, 3(1), 1-11.

Esteves de Araujo, J. F. F., \& Tejedo-Romero, F. (2016). Local government transparency index: determinants of municipalities' rankings. https://doi.org/10.1108/IJEBR-02-2016-0064

Ghozali, I. (2016). Aplikasi Analisis Multivariat dengan Program IBM SPSS 21 (8th ed.). Semarang: Badan Penerbit Universitas Diponegoro.

Governmental Accounting Standard Board. (1998). Govermental Accounting and Financial Reporting Standards. Nortwalk.

Loina, L. K. P. (2003). Indikator \& alat ukur prinsip akuntabilitas, transparansi \& partisipasi. Jakarta.

Mardiasmo. (2018). Akuntansi Sektor Publik (1st ed.). Yogyakarta: Andi Publisher.

Masyhur, M., Hardi, H., \& Silfi, A. (2017). Pengaruh penyajian laporan keuangan daerah, aksesibilitas laporan keuangan daerah dan pengendalian internal terhadap transparansi dan akuntabilitas pengelolaan keuangan daerah kota Dumai. Jurnal Online Mahasiswa Fakultas Ekonomi, 4(1), 1179-1192.

Mulyana, B. (2006). Pengaruh penyajian neraca daerah dan aksesibilitas laporan kenangan terbadap transparansi dan akuntabilitas pengelolaan kenangan daerah. Universitas Gadjah Mada.

Mustofa, A. I. (2012). Pengaruh penyajian dan aksesibilitas laporan keuangan terhadap akuntabilitas pengelolaan keuangan kabupaten Pemalang. Accounting Analysis Journal, 1(1), 1-6. 
Nordiawan, D. (2012). Akuntansi Sektor Publik. Jakarta: Salemba Empat.

Nunnally, J. C. (1967). Psychometric Theory. New York: McGraw-Hill.

Nurrizkiana, B., Handayani, L., \& Widiastuty, E. (2017). Determinan transparansi dan akuntabilitas pengelolaan keuangan daerah dan implikasinya terhadap kepercayaan public-stakeholders. Jurnal Akuntansi Dan Investasi, 18(1), 28-47.

Peraturan Pemerintah. (2008). Peraturan Pemerintah Republik Indonesia Nomor 60 Tahun 2008 tentang Sistem Pengendalian Intern Pemerintah. Sekretariat Negara. Jakarta

Peraturan Pemerintah. (2010). Peraturan Pemerintah Republik Indonesia Nomor 71 Tahun 2010 tentang Standar Akuntansi Pemerintah. Sekretariat Negara. Jakarta

Piotrowski, S. J., \& Ryzin, G. G. Van. (2007). Citizen attitudes toward transparency in local government. The American Review of Public Administration, 37(3), 306-323.

Rahmawati, R. A., \& Mahmudi, A. (2016). Faktor-faktor yang mempengaruhi transparansi pelaporan keuangan pemerintah daerah. Accounting Analysis Journal, 5(2), 122-130.

Safitri, R. A. (2009). Pengarub penyajian laporan keuangan daerah dan aksesibilitas laporan keuangan terbadap penggunaan informasi kenangan daerah (Studi empiris di kabupaten Semarang). Universitas Dipenogoro.

Sari, D. (2012). Pengaruh pengendalian internal terhadap transparansi laporan keuangan pemerintah daerah. In Seminar Nasional Akuntansi dan Bisnis (pp. 718-727). Bandung: SNAB.

Shende, S., \& Bennett, T. (2004). Transparency and accountability in public financial administration. In $R A B / 01 / 006$ : Transparency and accountability in the public sector in the Arab Region, Concept paper 2 (pp. 1-17). New York: UN DESA DPADM.

Sol, D. A. del. (2013). The institutional, economic and social determinants of local government transparency. Journal of Economic Policy Reform, 16(1), 90-107.

Sukhemi. (2010). Pengaruh penyajian nerca daerah terhadap akuntabilitas keuangan daerah. Akmenika Jurnal Akuntansi Dan Manajemen, 5(1), 85-100.

Yendrawati, R. (2013). Pengaruh sistem pengendalian intern dan kapasitas sumber daya manusia terhadap kualitas informasi laporan keuangan dengan faktor eksternal sebagai variabel moderating. Jurnal Akuntansi \& Auditing Indonesia, 17(2), 166-175.

Yogaperwira, P. S. (2008). Peranan laporan akuntabilitas kinerja instansi pemerintah (lakip) terhadap peningkatan kinerja instansi pemerintah daerah. Universitas Widyatama. 
JCA | Volume 1, No.1, 2019

\section{APPENDIX}

\section{Questionnaire}

Part 1: Respondent Characteristics

Name * (Can be left blank)

Gender
- Male
- Female

Education
○ Senior High School
○ Diploma/DIII
- S1
○ S2
○ S3

Working Period
○ $1-5$ years
○ 6-10 years
$\circ>10$ years

Part 2: Likert's Scale

\begin{tabular}{ccccc}
\hline 1 & 2 & 3 & 4 & 5 \\
\hline Strongly Disagree & Disagree & Doubt & Agree & Strongly Agree \\
\hline
\end{tabular}

The above scales show how you answer (agree/disagree) through the following statement items:

1. Financial Report Presentation

\begin{tabular}{cccccc}
\hline Item & 1 & 2 & 3 & 4 & 5 \\
\hline & $\begin{array}{c}\text { Strongly } \\
\text { Disagree }\end{array}$ & Disagree & Doubt & Agree & $\begin{array}{c}\text { Strongly } \\
\text { Agree }\end{array}$ \\
\hline
\end{tabular}

1. The regional government financial report possibly makes the users correct their expectation in the past.

2. The regional government financial report helps the users to predict the future based on the past results and the present activities.

3. The regional government financial report is always provided on time, so it is influential and useful for decision making.

4. The regional government financial report is provided completely covering all accounting information which is influential on the decision making. 
5. The regional government financial report describes the transactions and other activities honestly as well as is provided sufficiently as expected.

6. The information provided in the regional government financial report can be tested, and if the test were done more than once by different parties, the conclusion would not differently result.

7. The information provided in the regional government financial report can be understood by the users because it is termed as what the users know.

(Nurrizkiana et al., 2017)

2. Financial Report Accessibility

\begin{tabular}{|c|c|c|c|c|c|}
\hline \multirow[b]{2}{*}{ Item } & 1 & 2 & 3 & 4 & 5 \\
\hline & $\begin{array}{l}\text { Strongly } \\
\text { Disagree }\end{array}$ & Disagree & Doubt & Agree & $\begin{array}{c}\text { Strongly } \\
\text { Agree }\end{array}$ \\
\hline $\begin{array}{l}\text { 1. The regional government financial report is } \\
\text { published openly and is known by societies } \\
\text { through mass media. } \\
\text { 2. The societies can access the regional government } \\
\text { financial report easily. } \\
\text { 3. The regional government eases societies to access } \\
\text { information about the financial report. } \\
\text { Sande (2013) in Nurrizkiana et al., (2017) }\end{array}$ & & & & & \\
\hline
\end{tabular}

3. Internal Control System

\begin{tabular}{|c|c|c|c|c|c|}
\hline \multirow[b]{2}{*}{ Item } & 1 & 2 & 3 & 4 & 5 \\
\hline & $\begin{array}{l}\text { Strongly } \\
\text { Disagree }\end{array}$ & Disagree & Doubt & Agree & $\begin{array}{c}\text { Strongly } \\
\text { Agree }\end{array}$ \\
\hline $\begin{array}{l}\text { 1. There is an organizational structure which } \\
\text { differentiates jobs and functional responsibilities in } \\
\text { the construction of the regional government } \\
\text { financial report. }\end{array}$ & & & & & \\
\hline $\begin{array}{l}\text { 2. There are portions and procedures of recording in } \\
\text { giving sufficient guarantee and support to the } \\
\text { regional government financial report. }\end{array}$ & & & & & \\
\hline $\begin{array}{l}\text { 3. The regional government performs good practice } \\
\text { in conducting jobs and functions on each unit of } \\
\text { organization related to the function of the regional } \\
\text { government financial reporting. }\end{array}$ & & & & & \\
\hline $\begin{array}{l}\text { 4. The regional government has staffs/civil servants } \\
\text { who are qualified with the jobs and responsibilities } \\
\text { related to the financial report. } \\
\text { (Aditya \& Surjono, 2017) }\end{array}$ & & & & & \\
\hline
\end{tabular}


JCA | Volume 1, No.1, 2019

4. Financial Report Transparency

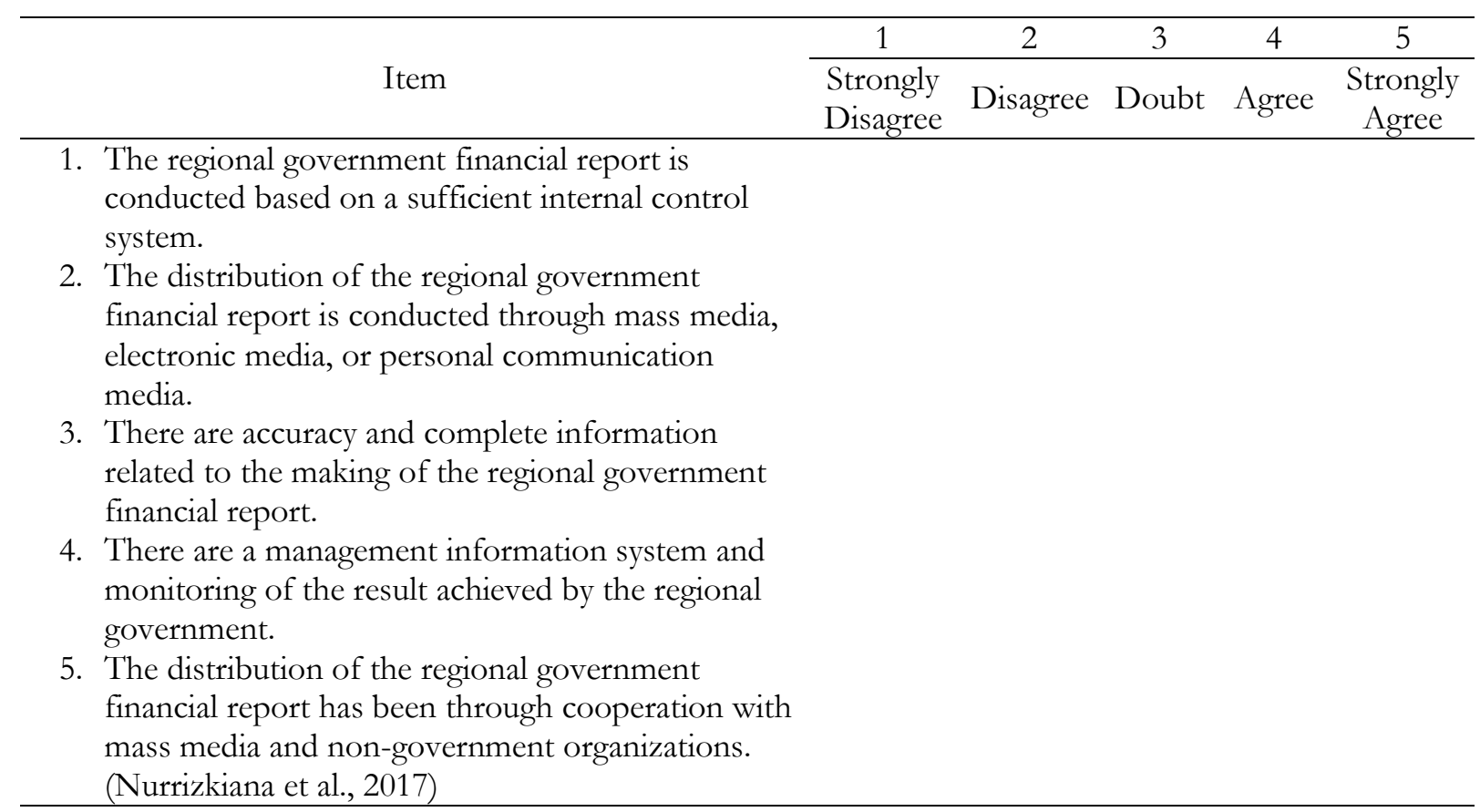

